\title{
Obesity and diabetes in transgenic mice expressing proSAAS
}

\author{
Suwen Wei, Yun Feng, Fa-Yun Che, Hui Pan ${ }^{1}$, Nino Mzhavia ${ }^{1}$, \\ Lakshmi A Devi ${ }^{1}$, Audra A McKinzie ${ }^{2}$, Nancy Levin ${ }^{2}$, \\ William G Richards ${ }^{2}$ and Lloyd D Fricker
}

\author{
Department of Molecular Pharmacology, Albert Einstein College of Medicine, 1300 Morris Park Avenue, Bronx, New York 10461, USA \\ ${ }^{1}$ Department of Pharmacology and Biological Chemistry, Mount Sinai School of Medicine, New York, New York 10029, USA \\ ${ }^{2}$ Department of Metabolic Disorders, Amgen, Thousand Oaks, California 91320, USA \\ (Requests for offprints should be addressed to Lloyd Fricker; Email: fricker@aecom.yu.edu) \\ (Nancy Levin is now at Pharmacology, X-Ceptor Therapeutics, Inc, San Diego, California 92121, USA)
}

\begin{abstract}
ProSAAS is a neuroendocrine peptide precursor that potently inhibits prohormone convertase 1 in vitro. To explore the function of proSAAS and its derived peptides, transgenic mice were created which express proSAAS using the beta-actin promoter. The body weight of transgenic mice was normal until approximately 10-12 weeks, and then increased 30-50\% over wild-type littermates. Adult transgenic mice had a fat mass approximately twice that of wild-type mice, and fasting blood glucose levels were slightly elevated. In the pituitary, the levels of several fully processed peptides in transgenic mice were not reduced compared with wild-type mice, indicating that the proSAAS transgene did not affect prohormone convertase 1 activity in this tissue.

Because the inhibitory potency of proSAAS-derived peptides towards prohormone convertase 1 is much greater
\end{abstract}

in the absence of carboxypeptidase E activity, the proSAAS transgene was also expressed in carboxypeptidase E-deficient Cpe fat fat mice. Although the transgenic mice were born in the expected frequency, 21 of 22 proSAAS transgenic Cpe fat fat mice died between 11 and 26 weeks of age, presumably due to greatly elevated blood glucose. The levels of several pituitary peptides were significantly reduced in the proSAAS transgenic Cpe fat fat mice relative to non-transgenic $C p e^{\text {fat fat }}$ mice, suggesting that the transgene inhibited prohormone convertase 1 in these mice. Taken together, these results are consistent with a role for proSAAS-derived peptides as neuropeptides that influence body weight independently of their function as inhibitors of prohormone convertase 1.

Journal of Endocrinology (2004) 180, 357-368

\section{Introduction}

Most neuropeptides, and many other proteins that transit the secretory pathway, are originally produced as precursors that undergo selected proteolysis. In many cases, the processing occurs at sites containing basic amino acids. First, a prohormone/proprotein convertase (PC) cleaves at the C-terminal side of the basic residue(s). Then, a carboxypeptidase (CP) removes the C-terminal basic amino acids. Several PCs have been reported, including PC1, PC2, and five others (Seidah \& Chretien 1998a,b, Zhou et al. 1999). In contrast to the relatively large number of PCs, only two CPs appear to function in the removal of C-terminal basic residues in the secretory pathway: CPE and CPD (Fricker 1998a,b, 2002). These enzymes differ in their primary site of action, with CPE more active at the acidic $\mathrm{pH}$ of the post-Golgi secretory vesicles, while $\mathrm{CPD}$ functions in the trans-Golgi network as well as within the exocytic and endocytic pathways.
Mice deficient in CPE activity due to a naturally occurring point mutation (i.e. the Cpe fat/fat mice) show a decrease in fully processed peptides and a large increase in the levels of processing intermediates containing C-terminal basic residues (Naggert et al. 1995, Fricker et al. 1996, Rovere et al. 1996, Cain et al. 1997, Udupi et al. 1997).

Several proSAAS-derived peptides were discovered using a strategy to isolate peptide substrates of CPE, based on their accumulation in Cpe fat fat mice (Fricker et al. 2000, Che et al. 2001). These peptides included big SAAS, little SAAS, and little LEN with C-terminal Arg-Arg extensions, PEN with a Lys-Arg extension, and KEP with an Arg extension (Fricker et al. 2000). Further studies in wild-type mice (Mzhavia et al. 2001) and in neuroendocrine cell lines (Mzhavia et al. 2002) showed that the major forms of these peptides lacked C-terminal basic residues, and also revealed additional peptides that were generated from proSAAS (Fig. 1). Although the proSAAS 
A

proSAAS

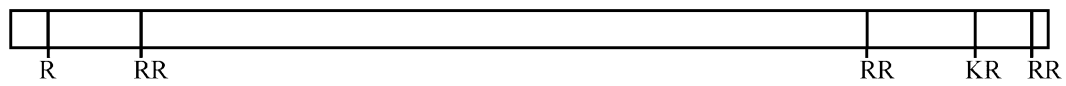

big SAAS $\square$
little SAAS $\square$
KEP $\square$

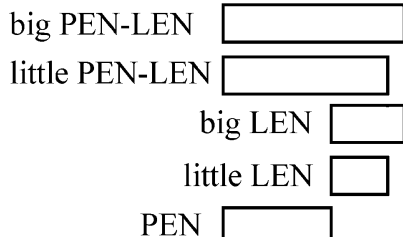

PEN

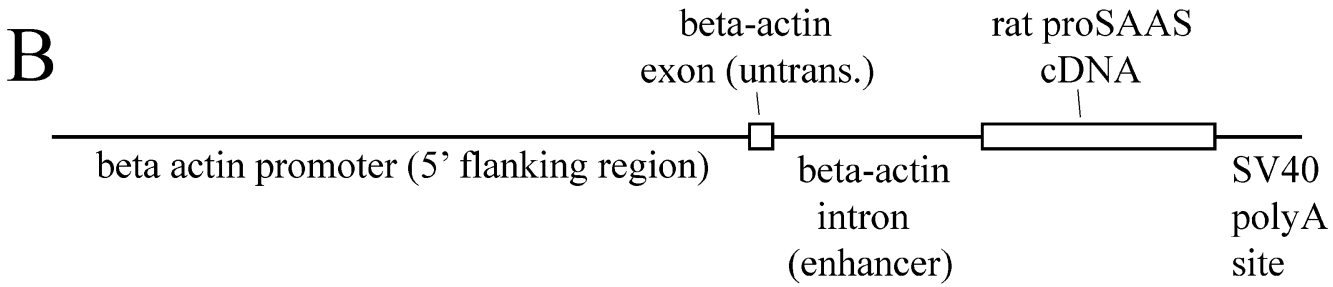

Figure 1 (A) Schematic diagram of proSAAS and the location of various proSAAS-derived peptides within this precursor. Singleand di-basic cleavage sites within proSAAS that give rise to the various peptides are indicated. Big PEN-LEN, little PEN-LEN, and PEN with a Lys-Arg extension on the C-terminus are the only proSAAS-derived peptides found to inhibit PC1. (B) Schematic diagram of the transgenic construct, which consisted of the beta-actin promoter and $5^{\prime}$ flanking region ( $\left.3 \mathrm{~kb}\right)$, the untranslated beta-actin exon 1 (78 bp), the beta-actin intron and enhancer element (1 kb), rat proSAAS cDNA (1 kb) and the SV40 polyadenylation site $(0 \cdot 3 \mathrm{~kb})$.

protein does not have significant sequence similarity to any other entry in the GenBank database, the general size, amino acid composition, and distribution of the proSAAS protein are similar to that of $7 \mathrm{~B} 2$, an endogenous inhibitor of PC2 (Marcinkiewicz et al. 1987, Martens et al. 1994, Cameron et al. 2000). ProSAAS was found to potently inhibit PC1 in vitro (Fricker et al. 2000), and further studies determined that the inhibitory region of proSAAS was the 6-8 amino acid region surrounding the junction of PEN and LEN (Cameron et al. 2000, Qian et al. 2000, Basak et al. 2001). Thus, while big and little forms of PEN-LEN inhibit PC1 with low nanomolar affinity, fully processed LEN and PEN are inactive as inhibitors. Interestingly, PEN-Lys-Arg is also a potent inhibitor of PC1, indicating that the carboxypeptidase step is important in regulating the PC1-inhibitory activity of this peptide (Cameron et al. 2000).

Because only a relatively small region of proSAAS functions as a PC1 inhibitor, and several of the other regions are highly conserved between human and rodents, it is likely that proSAAS-derived peptides perform additional functions, possibly as neuropeptides. Recently, proSAAS was identified in a screen of proteins that are altered in the cerebrospinal fluid of people with frontotemporal dementia (Davidsson et al. 2002). The level of a $20 \mathrm{kDa}$ fragment of proSAAS was decreased approximately $75 \%$ in the patients with frontotemporal dementia, although it is not clear if the changes in proSAAS contribute in any way to the dementia or are merely secondary changes as a result of the disease. To gain insights into possible functions of proSAAS-derived peptides, we created transgenic mice overexpressing proSAAS. In addition to expressing the transgene in mice with normal levels of CPE, we also expressed the proSAAS transgene in CPE deficient Cpe fat fat mice in order to increase the levels of PEN-Lys-Arg and thus produce a greater inhibition of PC1.

\section{Materials and Methods}

\section{Creation of transgenic mice}

All animal experimentation described in this report was conducted in accord with accepted standards of humane animal care, as outlined in the Ethical Guidelines of the Albert Einstein College of Medicine. A construct utilizing 
the $\beta$-actin promoter (Graham et al. 1997) to drive expression of full-length rat proSAAS cDNA (Fig. 1B) was used to create proSAAS transgenic mice in the B6D2F1 strain. Three hemizygous founder mice were demonstrated to be transgenic proSAAS-positive. Transgenic mouse line 32 (deriving from founder mouse \#32) was further bred for several generations in the BDF strain and then backcrossed to the C57 BKS strain for five generations. Mice were maintained in a daily cycle of $12 \mathrm{~h}$ light $/ 12 \mathrm{~h}$ darkness and allowed free access to water and chow (Lab diet 5058, Purina Mills Inc., Richmond, IN, USA). Male ProSAAS transgenic mice that had been backcrossed to C57 BKS were bred with female heterozygote Cpe fat/+ mice (The Jackson Laboratory, Bar Harbor, ME, USA). The progeny that were Cpe fat $/+$ and proSAAS transgene-positive $\left(\mathrm{Tg}^{+}\right)$were then crossed with Cpe fat/+ mice to obtain proSAAS $\mathrm{Tg}^{+} C p e^{\text {fat fat }}$ mice, in addition to $\mathrm{Tg}^{-} C p e^{\text {fat fat }}$ mice, $\mathrm{Tg}^{+} \mathrm{Cp} e^{+/+}$mice, and $\mathrm{Tg}^{-} \mathrm{Cpe}^{+/+}$mice.

\section{Analysis of proSAAS $m R N A$ and peptide levels}

Oligonucleotide primers and fluorogenic probe combinations for TaqMan assays were designed using Primer Express v1.0 (Applied Biosystems, Foster City, CA, USA). For detection of endogenous mouse proSAAS mRNA, the forward primer (5'-AGGAGGCCGAGAG ACAGGAA-3'), reverse primer (5'-GCGCCTGCTGA TCCTCA-3'), and probe (5'-FAM-CTCCTGCGCCT CAGCACGCG-TAMRA-3') were specific for mouse SAAS and did not amplify the rat SAAS transgene. Rat SAAS transgene expression was detected by a forward primer (5'-CCAGACATGATAAGATACATTGATGA GTTT-3'), reverse primer (5'-AAAGCAATAGCATCA CAAATTTCACA-3 $\left.{ }^{\prime}\right)$, and probe $\left(5^{\prime}\right.$-FAM-ACAAA CCACAACTAGAATGCAGTGAAAAAAATGCTTT TAMRA-3') designed against the SV40 poly-A portion of the rat proSAAS transgene construct. These primers did not produce any PCR amplification product in samples from $\mathrm{Tg}^{-}$mice. All proSAAS TaqMan reactions were normalized against the expression levels of mouse cyclophilin mRNA using a forward primer $\left(5^{\prime}\right.$-CAAATG CTGGACCAAACACAA-3'), reverse primer (5'GCCTTCTTTCACCTTCCCAAA-3'), and probe (5'FAMTTCCCAGTTTTTTATCTGCACTGCCAAGA TAMRA-3') specific for mouse cyclophilin.

Total RNA was isolated from whole mouse brains using Trizol reagent (Invitrogen) according to the manufacturer's instructions, and treated with DNaseI (Invitrogen) prior to reverse transcription to remove contaminating DNA. Reverse transcription was performed with $5 \mu \mathrm{g}$ total RNA using the Superscript Preamplification System for First Strand cDNA Synthesis (Invitrogen) according to the supplier's protocol, and diluted in water to a final volume of $300 \mu \mathrm{l}$.
Quantitative real-time PCR assays were performed using the ABI PRISM 7700 TaqMan sequence detector and Sequence Detector v1.6 (Applied Biosystems). Reactions were performed in triplicate using the TaqMan PCR Core Reagent kit (Applied Biosystems). Each reaction contained $1 \times$ TaqMan buffer A, $5 \mathrm{mM} \mathrm{MgCl}_{2}$, $0.2 \mathrm{mM}$ each of dATP, dCTP, dGTP, dUTP, $70 \mathrm{nM}$ each of the forward and reverse primer, $100 \mathrm{nM}$ probe, $0.5 \mathrm{U}$ Amperase UNG, 1.25 U AmpliTaq Gold, and $10 \mu \mathrm{l}$ first strand cDNA in a final volume of $50 \mu$ l. Thermal cycling conditions were $2 \mathrm{~min}$ at $50{ }^{\circ} \mathrm{C}, 10 \mathrm{~min}$ at $95^{\circ} \mathrm{C}$ followed by 40 cycles of $15 \mathrm{~s}$ at $95^{\circ} \mathrm{C}$ and $1 \mathrm{~min}$ at $60{ }^{\circ} \mathrm{C}$.

For analysis of proSAAS peptides, brains were frozen in liquid nitrogen and ground into a fine powder. Ten volumes $0 \cdot 1 \mathrm{M}$ boiling acetic acid were added, and then the samples were mixed, incubated for $15 \mathrm{~min}$ at $100{ }^{\circ} \mathrm{C}$, cooled on ice, and centrifuged for $30 \mathrm{~min}$ at $12000 \mathrm{~g}$. The supernatants were removed, dried in a vacuum centrifuge, and rehydrated in buffer A $(100 \mathrm{mM}$ sodium phosphate pH 7.4 containing $0 \cdot 1 \%$ Triton X-100). The samples were applied to a Superdex Peptide HR 10/30 gel-exclusion column (Amersham Bioscience) and fractionated in 30\% acetonitrile and $0 \cdot 1 \%$ trifluoroacetic acid. The flow rate was $0.5 \mathrm{ml} / \mathrm{min}$. One-minute fractions were collected, dried, and resuspended in buffer A. Immunoreactive- (ir-) LEN peptide was determined by radioimmunoassay (RIA) using an antiserum to big LEN (rabbit number 85) as described previously (Mzhavia et al. 2001).

\section{Food consumption and body fat determination}

Total cumulative food consumption was measured for one week in individually housed female proSAAS $\mathrm{Tg}^{+}$and $\mathrm{Tg}^{-}$mice that were 10 weeks of age. Average daily consumption was determined ( $\mathrm{g} /$ day).

For the determination of body fat, five male proSAAS $\mathrm{Tg}^{+}$and five age-matched $\mathrm{Tg}^{-} \mathrm{Cpe}^{+/+}$mice were killed with $\mathrm{CO}_{2}$ vapors. The inguinal, retroperitoneal, scapular, reproductive and mesenteric fat pads were removed and weighed. The individual weight of each fat pad was calculated as a percentage of total body weight. The results were analyzed using Student's $t$-test.

\section{Analysis of plasma levels of glucose and other substances}

Three to four mice from each of the four groups (proSAAS $\mathrm{Tg}^{+} \mathrm{Cpe}^{+/+}, \mathrm{Tg}^{-} \mathrm{Cpe} e^{+/+}, \mathrm{Tg}^{+} C p e^{\text {fat fat }}$, and $\mathrm{Tg}^{-}$ Cpe $e^{\text {fat fat }}$ mice) were killed by decapitation and the blood collected. Sera from the animals were analyzed for several standard biochemical markers (Antech Diagnostics, Farmingdale, NY, USA).

For analysis of fasting glucose levels, mice were deprived of food from $2200 \mathrm{~h}$ and blood was taken at $1000 \mathrm{~h}$ the next day. Approximately $50 \mu \mathrm{l}$ blood were withdrawn from the tail using a heparinized microhematocrit capillary tube (Fisher Scientific, Pittsburgh, 
PA, USA) and transferred to a polyethylene heparinlithium coated microfuge tube (Beckman Instrument Inc. Palo Alto, CA, USA). Plasma was collected after centrifugation at $7200 \mathrm{~g}$ for $5 \mathrm{~min}$. Fasting glucose levels were analyzed using Glucose Analyzer 2 (Beckman Instrument Inc.).

Insulin levels were measured by RIA using an antiserum raised against rat insulin which cross reacts 100\% with mouse insulin (Linco Research, St Charles, MO, USA). The cross reactivity of this antiserum to mouse proinsulin and to mouse proinsulin-processing intermediates is unknown; this antiserum has a $69 \%$ cross reactivity to human proinsulin.

\section{Analysis of relative levels of pituitary peptides}

In order to quantitate peptide levels using mass spectrometry, we used a quantitative peptidomics strategy that employs differential isotopic labels $\left(\mathrm{H}_{6}\right.$ and $\left.\mathrm{D}_{6}-\mathrm{Ac}_{2} \mathrm{O}\right)$ as described (Che \& Fricker 2002). In one experiment, eight proSAAS $\mathrm{Tg}^{+} \mathrm{Cpe}+/+$ mice were compared with eight age- and sex-matched $\mathrm{Tg}^{-} \mathrm{Cpe}^{+/+}$mice. In another experiment, four proSAAS $\mathrm{Tg}^{+} C p e^{\text {fat fat }}$ mice were compared with four age- and sex-matched $\mathrm{Tg}^{-}$Cpe fat/fat mice. Extraction and acetylation of pituitary peptides was performed as previously described (Che \& Fricker 2002). Briefly, $100 \mu$ boiling $10 \mathrm{mM} \mathrm{HCl}$ were added to a microfuge tube containing a single pituitary gland of $\mathrm{Tg}^{+}$ or $\mathrm{Tg}^{-}$mice $\left(\mathrm{Cpe}^{+/+}\right.$or $\left.C p e^{\text {fat } f a t}\right)$. The tissue was incubated in a boiling water bath for $10 \mathrm{~min}$ and then sonicated for $5 \mathrm{~s}$. The $\mathrm{HCl}$ extract was neutralized with $1 \mu \mathrm{l} 1.0 \mathrm{M} \mathrm{NaOH}$ followed by the addition of $200 \mu \mathrm{l}$ $0 \cdot 2 \mathrm{M} \mathrm{NH}_{4} \mathrm{HCO}_{3}, \mathrm{pH} 7 \cdot 5$. Acetylation was carried out by adding $12 \mu \mathrm{H}_{6}-\mathrm{Ac}_{2} \mathrm{O}$ or $\mathrm{D}_{6}-\mathrm{Ac}_{2} \mathrm{O}$ to the homogenate. For normal labeling, the $\mathrm{Tg}^{-}$extract was labeled with $\mathrm{H}_{6}-\mathrm{Ac}_{2} \mathrm{O}$ while the $\mathrm{Tg}^{+}$extract was labeled with $\mathrm{D}_{6}-$ $\mathrm{Ac}_{2} \mathrm{O}$. For reverse labeling, the $\mathrm{Tg}^{-}$extract was labeled with $\mathrm{D}_{6}-\mathrm{Ac}_{2} \mathrm{O}$ while the $\mathrm{Tg}^{+}$extract was labeled with $\mathrm{H}_{6}-\mathrm{Ac}_{2} \mathrm{O}$. Generally, normal labeling was carried out for half of the $\mathrm{Tg}^{+}$and $\mathrm{Tg}^{-}$mice and reverse labeling for the other half of the mice. After acetylation, the $\mathrm{H}_{6}-\mathrm{Ac}_{2} \mathrm{O}-$ labeled samples and the $\mathrm{D}_{6}-\mathrm{Ac}_{2} \mathrm{O}$-labeled samples from age- and sex-matched mice were pooled and centrifuged at $50000 \mathrm{~g}$ for $30 \mathrm{~min}$ at $4{ }^{\circ} \mathrm{C}$. The supernatant was removed and filtered through a Centricon YM-10 membrane (Amicon. Beverly, MA, USA). Finally, the filtrate was desalted with ZipTip $\mathrm{C}_{18}$ (Millipore, Billerica, MA, USA) and analyzed by matrix-assisted laser desorption ionization, time-of-flight, mass spectrometry (MALDI-TOF-MS).

MALDI-TOF-MS analysis was performed in the delayed extraction linear positive mode on a VoyagerDE STR mass spectrometer (PerSeptive Biosystems, Framingham, MA, USA). Typically, aliquots $(0 \cdot 5 \mu \mathrm{l})$ of ZipTip $\mathrm{C}_{18}$ desalted sample were mixed with $1 \mu \mathrm{l} \mathrm{mg} /$ $\mathrm{ml} \alpha$-cyano-4-hydroxycinnamic acid in $50 \%$ acetonitrile and $0 \cdot 1 \%$ trifluoroacetic acid. About $1 \mu \mathrm{l}$ of the mixture was loaded onto the MALDI-TOF-MS sample plate and allowed to dry in the open air. For each sample, the spectra obtained from 150 laser shots were accumulated. External multipoint mass calibration was carried out with des-Arg1bradykinin $\left([\mathrm{MH}]^{+}\right.$904.448), angiotensin I $\left([\mathrm{MH}]^{+}\right.$ 1296.685), little SAAS $\left([\mathrm{MH}]^{+} 1784 \cdot 978\right)$, PEN $\left([\mathrm{MH}]^{+}\right.$ $2301 \cdot 248)$ and big SAAS $\left([\mathrm{MH}]^{+} 2720 \cdot 148\right)$.

Relative levels of peptides between $\mathrm{Tg}^{+}$and $\mathrm{Tg}^{-}$mice were measured by the ratio of peak intensity of the $\mathrm{H}_{3}$-Ac- and $\mathrm{D}_{3}$-Ac-labeled peptide pairs, as described (Che \& Fricker 2002). Peptides were identified by comparing the observed parent mass of each peptide (after subtraction of the added acetyl groups) to the theoretical mass of peptides that were previously identified in pituitary extracts (Feistner et al. 1989, Young et al. 1993, Jimenez et al. 1997, Che et al. 2001, Che \& Fricker 2002).

\section{Immunohistochemistry of proinsulin in pancreas}

For immunohistochemistry, $5-\mu \mathrm{m}$ thick sections of paraffin-embedded pancreas from age- and sex-matched animals were deparaffinized with two changes of xylene and rehydrated. The slides were bathed in $3 \% \mathrm{H}_{2} \mathrm{O}_{2}$ for $15 \mathrm{~min}$ at $37^{\circ} \mathrm{C}$ to quench endogenous peroxidase and then heated in a microwave oven in citrate antigen retrieval solution $(0 \cdot 1 \mathrm{M}$ sodium citrate, $\mathrm{pH} 6 \cdot 0$, with $0 \cdot 01 \%$ Triton $\mathrm{X}-100)$ to allow the epitopes to reconfigure. Sections were incubated for $2 \mathrm{~h}$ at room temperature in blocking buffer (NEN Life Science, Boston, MA, USA) containing a 1:2000 dilution of monoclonal mouse anti-human proinsulin antibody (the gift of Dr Ole Madsen, Hagedorn Research Institute, Gentofte, Denmark). Sections were washed in phosphate-buffered saline with $0 \cdot 2 \%$ Tween-20, pH $7 \cdot 4$, exposed to biotinylated anti-mouse immunoglobulin (DAKO LSAB system, Glostrup, Denmark) for 20 min, washed, followed by incubation in streptavidin-horseradish peroxidase for $20 \mathrm{~min}$ and washed in the same buffer. The staining was visualized with liquid diaminobenzidine chromogen for $2 \mathrm{~min}$ and stopped by washing in water. The slides were then counterstained and observed under a light microscope. The images were captured from an attached camera using Kodak Ektachrome 64T film.

\section{Western blot analysis of PC1}

Brain tissues were frozen in liquid nitrogen, ground to a fine powder, and homogenized in 10 volumes $50 \mathrm{mM}$ Tris- $\mathrm{HCl} \mathrm{pH} \mathrm{7.4}$ containing 1\% Triton X-100, $10 \%$ glycerol, and a protease inhibitor cocktail (Sigma P8340). Homogenates were kept on ice for $30 \mathrm{~min}$ to allow proteins to solubilize and then fractionated on an SDS-polyacrylamide gel and transferred to a nitrocellulose membrane. The membrane was probed with a 1:1000 dilution of rabbit polyclonal antiserum raised against the 
N-terminal region of PC1 (Vindrola \& Lindberg 1992). Equal loading was confirmed by blotting with anti-tubulin antiserum (Sigma).

\section{Results}

Three founder mice were positive for proSAAS expression. One of these was extremely obese (approximately $70 \mathrm{~g}$ at 45 weeks) but was sterile. Post-mortem analysis using real-time quantitative PCR revealed that the level of proSAAS mRNA in the brain of this mouse was fivefold higher than in wild-type mice (data not shown). A second mouse (\#32) was fertile and moderately overweight, and expressed proSAAS mRNA in the brain at a level approximately twofold that of wild-type mice (data not shown). A third proSAAS-positive mouse (\#29) was also fertile but was not overweight. This mouse expressed proSAAS mRNA in the brain at a level that was not substantially different from wild-type mice; this line was not investigated further.

Mouse \#32 was crossed into the C57 BKS background, which is more sensitive to the development of hyperglycemia than other strains (Naggert et al. 1995). Also, this strain was chosen so that the transgene could also be expressed in CPE-deficient Cpe ${ }^{\text {fat fat }}$ C57 BKS mice. In proSAAS transgene-positive CPE-normal C57 BKS mice $\left(\mathrm{Tg}^{+} \mathrm{Cpe} e^{+/+}\right.$mice), the level in brain of ir-LEN, a proSAAS-derived peptide, was elevated $60-90 \%$ over the level in $\mathrm{Tg}^{-} \mathrm{Cpe}^{+/+}$mice. The processing of proSAAS in brain was examined using gel filtration followed by RIA. The size of the ir-LEN in the proSAAS $\mathrm{Tg}^{+}$mice was identical to that in $\mathrm{Tg}^{-}$mice (Fig. 2), indicating that the overexpression does not lead to any alteration in the extent of the processing.

The transgenic mice were born in the expected frequency. From a series of matings involving proSAAS $\mathrm{Tg}^{+}$ mice with either wild-type or other proSAAS $\mathrm{Tg}^{+}$mice, $137 \mathrm{Tg}^{+}$mice were obtained (147 expected) and $71 \mathrm{Tg}^{-}$ mice were obtained (61 expected). Similarly, when proSAAS $\mathrm{Tg}^{+} \mathrm{Cpe}^{\text {fat } /+}$ mice were crossed, 38 of the Cpe fat fat offspring were $\mathrm{Tg}^{+}$(42 expected) and 17 were $\mathrm{Tg}^{-}$(14 expected). While the $\mathrm{Tg}^{+}$mice in the CPE-normal $\left(\mathrm{Cpe}^{+/+}\right)$mice appeared healthy and none of the mice died within 35 weeks, the transgene greatly increased the mortality in the CPE-deficient Cpe fat fat mice (proSAAS $\mathrm{Tg}^{+}$Cpe $e^{\text {fat /fat }}$, Fig. 3). Whereas slightly less than half of the $\mathrm{Tg}^{-}$Cpe fat/fat mice died by 35 weeks, 21 out of $22 \mathrm{Tg}^{+}$ Cpe fatffat mice died between 11 and 26 weeks (Fig. 3). There was no major difference in the average age of death of male versus female $\mathrm{Tg}^{+} \mathrm{Cpe} e^{\text {fat fat }}$ mice.

The body weight of proSAAS $\mathrm{Tg}^{+} \mathrm{Cpe}^{+/+}$mice was comparable to $\mathrm{Tg}^{-} \mathrm{Cpe}^{+/+}$littermates until about 10-12 weeks of age, and then the $\mathrm{Tg}^{+}$animals showed a steady weight gain to a maximum of approximately $30 \mathrm{~g}$, compared with 20-24 g for the $\mathrm{Tg}^{-}$mice (Fig. 4, panels A

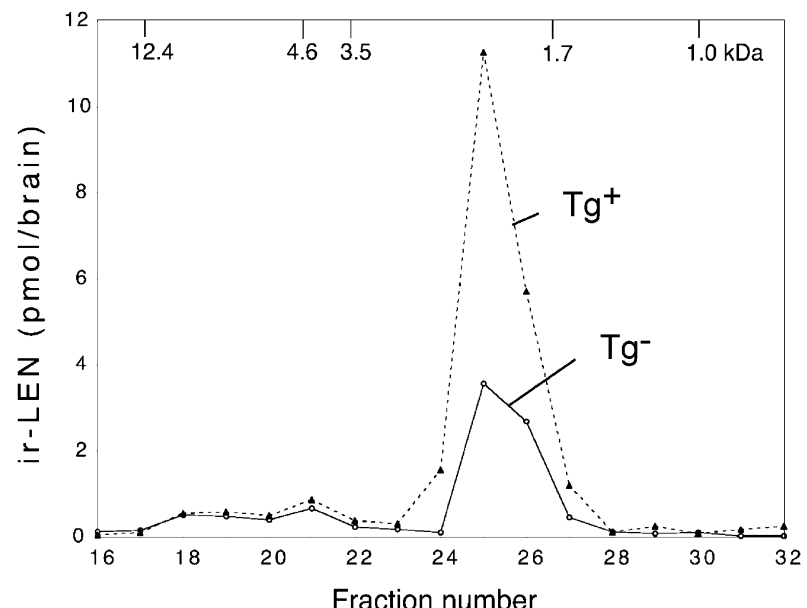

Figure 2 Gel filtration analysis of ir-LEN in proSAAS $\mathrm{Tg}^{+}$(dashed line) and $\mathrm{Tg}^{-}$(solid line) Cpe ${ }^{+/+}$mice. Extracts from each brain were subjected to gel filtration chromatography on a Superdex Peptide HR 10/30 column. Fractions were analyzed for ir-big LEN as described in Materials and Methods. Molecular mass standards are indicated at the top. The peak at approximately $2 \mathrm{kDa}$ represents the mature form of LEN. The indicated results represent the brains from individual mice. Similar experiments with two additional mice showed the same result.

and B). This change in body weight does not appear to be due to hyperphagia; $\mathrm{Tg}^{+}$Cpe fat/fat female mice at 10 weeks ate $2.94 \pm 0.30 \mathrm{~g}$ food per day, while $\mathrm{Tg}^{-}$

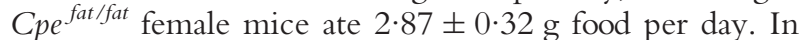
contrast to the effect of the transgene in $\mathrm{Cpe}^{+/+}$mice, the body weight of the proSAAS $\mathrm{Tg}^{+} \mathrm{CPE}$-deficient Cpe fat/fat

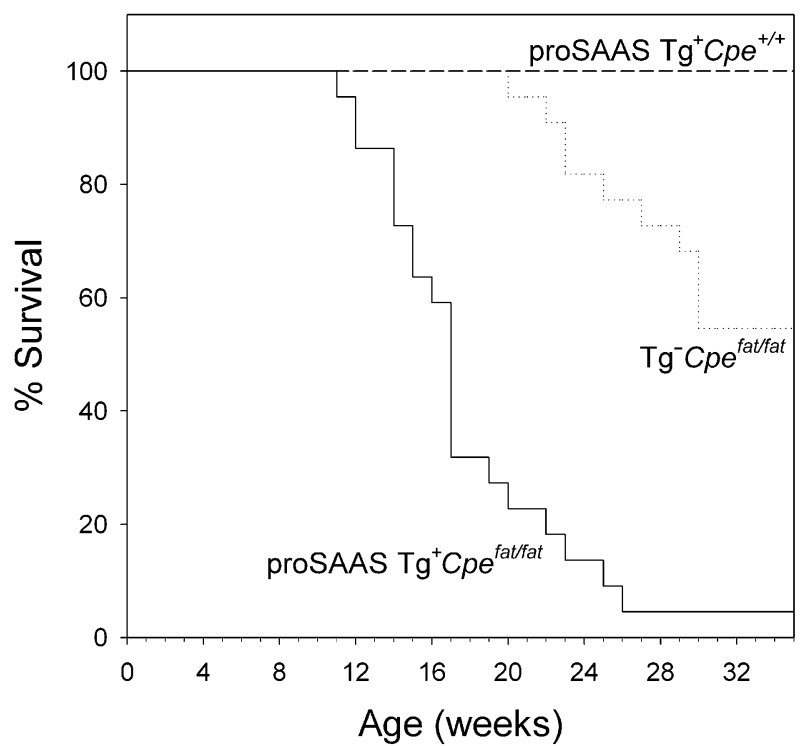

Figure 3 Survival of proSAAS $\mathrm{Tg}^{+} \mathrm{Cpe}^{\text {fat/fat }}$ mice (solid line, $n=22)$, proSAAS $\mathrm{Tg}^{+} \mathrm{Cpe}^{+/+}$mice (dashed line, $n=11$ ), and $\mathrm{Tg}^{-}$ $\mathrm{Cpe}^{\text {fat/fat }}$ mice (dotted line, $n=22$ ). The time of death or when mice became moribund is indicated (in weeks). 

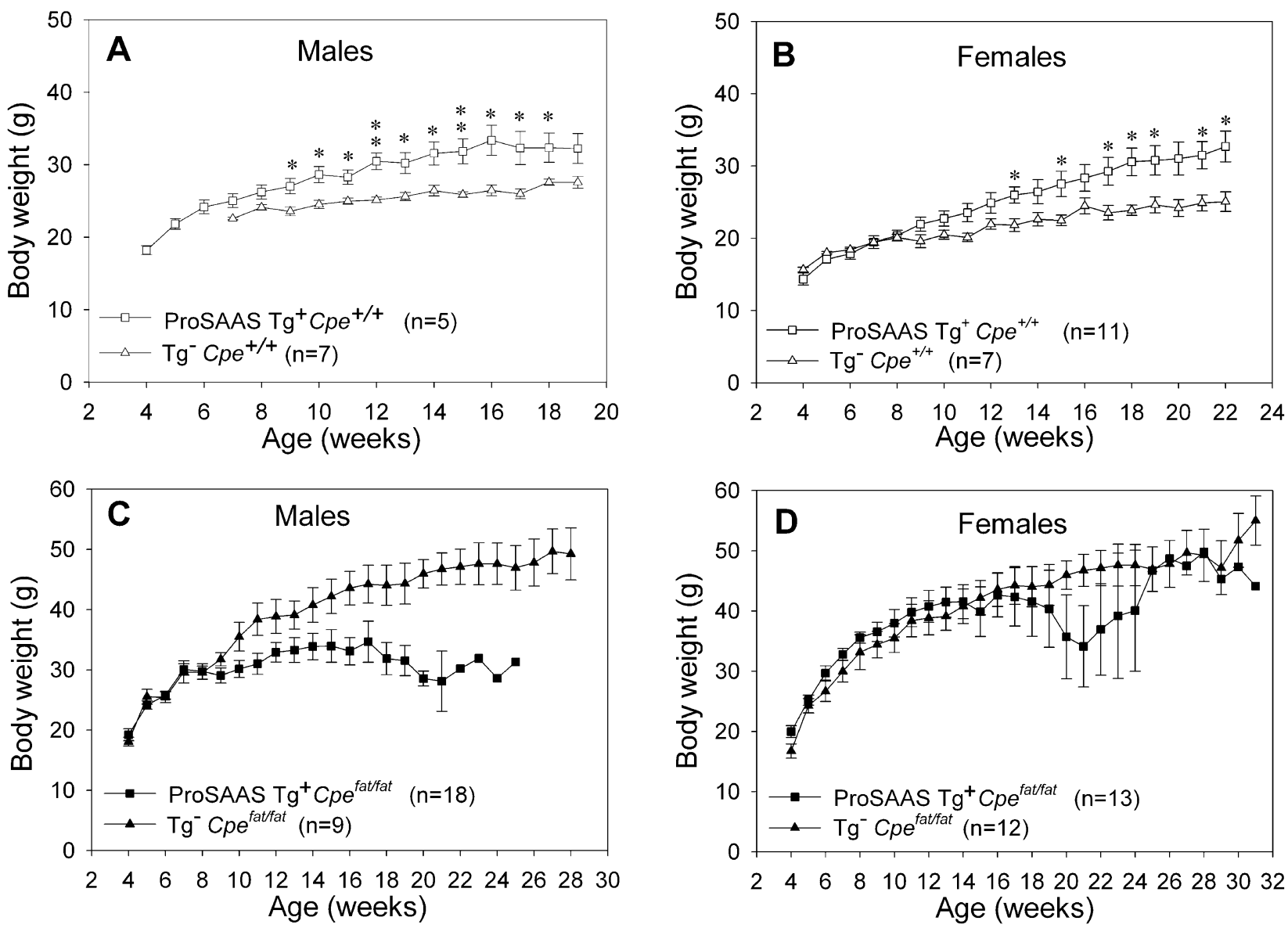

Figure 4 Body weight versus age for proSAAS $\mathrm{Tg}^{+}$and $\mathrm{Tg}^{-}$mice. (A) Male Cpe ${ }^{+/+}$mice; (B) female Cpe ${ }^{+/+}$mice; (C) male Cpe ${ }^{\text {fat/fat }}$ mice; (D) female Cpe fat/fat mice. Data were analyzed using SigmaPlot software (SPSS Inc., Chicago, IL, USA). Values are expressed as means \pm standard error of the mean. ${ }^{*} P<0.05$ compared with $\mathrm{Tg}^{-}$mice, ${ }^{* *} P<0.01$ compared with $\mathrm{Tg}^{-}$mice using Student's $t$-test. ProSAAS $\mathrm{Tg}^{+}$mice are indicated with squares and $\mathrm{Tg}^{-}$mice with triangles. The $n$ value indicated in the Figure represents the number of animals at the start of the measurements through 12 weeks; for the proSAAS Tg ${ }^{+} \mathrm{Cpe}^{\text {fat/fat }}$ mice (square symbols, panels C and D) the number of animals decreased substantially throughout the study due to the high mortality rate (Fig. 3) and the last 2-4 measurements of these groups represent single animals.

mice was lower than that of the $\mathrm{Tg}^{-}$Cpe fat fat mice (Fig. 4, panels $\mathrm{C}$ and $\mathrm{D})$. However, these differences were not statistically significant due to the small number of animals that survived past 16 weeks. Analysis of individual mice showed a dramatic loss in weight in the week or two before death.

Individual fat pads from $\mathrm{Tg}^{+}$and $\mathrm{Tg}^{-} \mathrm{Cpe}^{+/+}$mice were isolated and compared. The inguinal and reproductive fat pads from the $\mathrm{Tg}^{+}$mice were approximately twice the fraction of body weight of the comparable fat pads from $\mathrm{Tg}^{-}$mice (Fig. 5). The scapular, the retroperitoneal and the mesenteric fat pads also showed a tendency to be larger in the $\mathrm{Tg}^{+}$mice, although the differences were not statistically significant (Fig. 5).

To determine if there were any major differences in serum chemistry, plasma samples from a small number of animals were analyzed (Table 1). Serum glucose levels were higher in the Cpe fat/fat mice relative to the $C p e^{+/+}$ mice, as previously reported (Naggert et al. 1995, Leiter et al. 1999), and the presence of the proSAAS transgene further elevated this parameter to $>1000 \mathrm{mg} / \mathrm{dl}$ (Table 1). Cholesterol was also significantly elevated in the $\mathrm{Tg}^{+}$ Cpe fat fat mice, relative to $\mathrm{Tg}^{-}$Cpe fat fat mice, but this parameter was not statistically different between the $\mathrm{Tg}^{+}$ and $\mathrm{Tg}^{-} \mathrm{Cpe}^{+/+}$mice. Blood urea nitrogen/creatinine was significantly higher in $\mathrm{Tg}^{+} \mathrm{Cpe}^{+/+}$mice relative to $\mathrm{Tg}^{-} \mathrm{Cpe} e^{+/+}$mice but was not different between $\mathrm{Tg}^{+}$and $\mathrm{Tg}^{-}$Cpe ${ }^{\text {fat fat }}$ mice (Table 1). There were no statistically significant differences in any of the other parameters, either between $\mathrm{Tg}^{+}$and $\mathrm{Tg}^{-}$mice, or between $\mathrm{Tg}^{-}$ Cpe fat/fat mice and $\mathrm{Tg}^{-} \mathrm{Cpe}^{+/+}$mice (Table 1). To further examine the effect of the transgene on glucose levels, fasted animals were examined for serum glucose levels. There was a small but statistically significant 


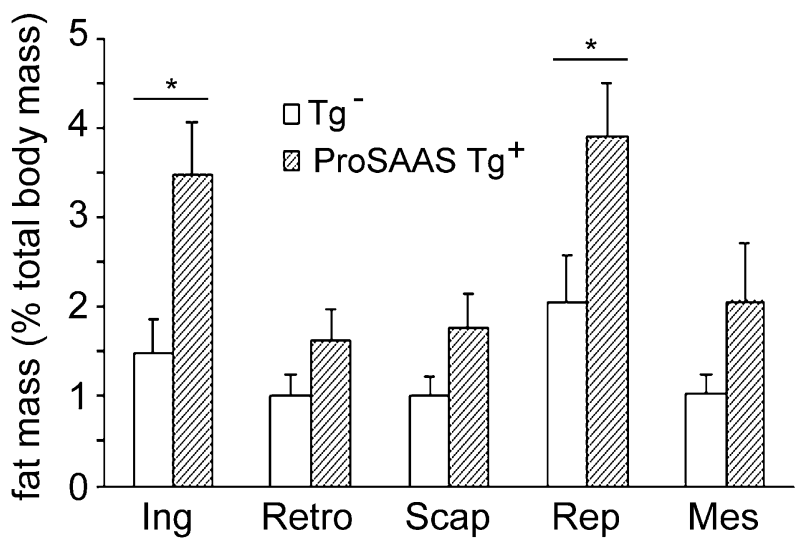

Figure 5 Body fat mass (\% total body weight) in $\mathrm{Tg}^{-} \mathrm{Cpe}^{+/+}$ (open bars) and proSAAS Tg Cpe ${ }^{+/+}$male mice (shaded bars). The mice were age-matched between groups and ranged from 25 to 40 weeks. Fat pads: Ing, inguinal; Retro, retroperitoneal; Scap, scapular; Rep, reproductive; Mes, mesenteric. Values are expressed as means \pm standard error of the mean; ${ }^{*} P<0 \cdot 05$ compared with $\mathrm{Tg}^{-}$mice $(n=5)$ using Student's $t$-test.

increase in fasting serum glucose levels in both male and female $\mathrm{Tg}^{+} \mathrm{Cpe}^{+/+}$mice, relative to $\mathrm{Tg}^{-} \mathrm{Cpe}^{+/+}$mice (Fig. 6). As previously found (Naggert et al. 1995, Leiter et al. 1999), the fasting serum glucose level in male $C p e^{\text {fat } / f a t}$ mice was higher than in female Cpe fat/fat mice. The proSAAS transgene further elevated serum glucose in both male and female $C p e^{\text {fat/fat }}$ mice, although this increase was only statistically significant in the female mice (Fig. 6).

Serum insulin levels were examined in proSAAS $\mathrm{Tg}^{+}$ and $\mathrm{Tg}^{-} \mathrm{Cpe}^{+/+}$mice following a 4-h fast (Table 2). Although the 4.5 to 6 month old $\mathrm{Tg}^{+}$females showed a tendency for lower insulin levels than the $\mathrm{Tg}^{-}$mice, this difference was not statistically significant. The male $\mathrm{Tg}^{+}$ mice showed a tendency for higher insulin levels at the

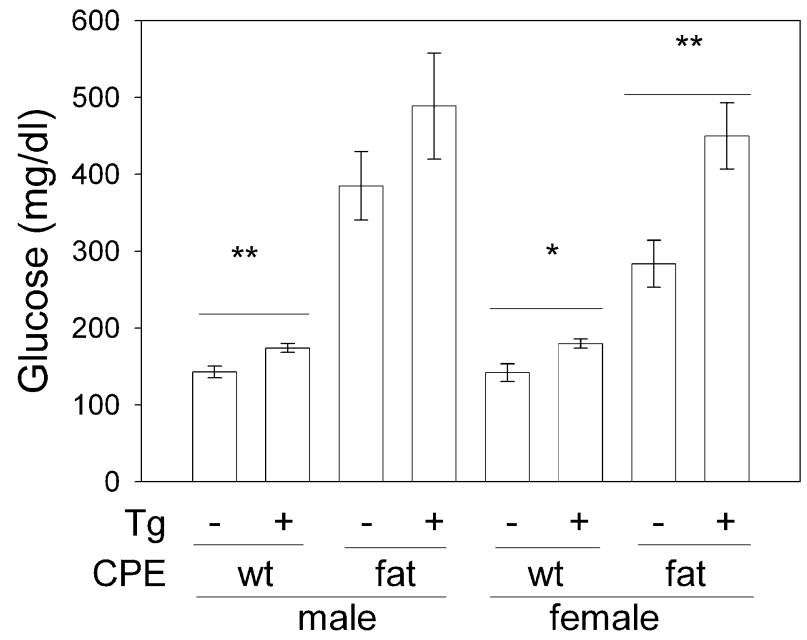

Figure 6 Comparison of fasting glucose levels in mice of different genotypes at the age of 14-19 weeks. Data were analyzed using SigmaPlot software. Values are expressed as means \pm standard error of the mean; ${ }^{*} P<0 \cdot 05,{ }^{*} P<0.01$ for the comparison indicated by the horizontal bar, using Student's t-test. The genotype and number of measurements in each group are (from left to right), $\mathrm{Tg}^{-} \mathrm{Cpe}^{+/+}$males $(n=7)$, proSAAS $\mathrm{Tg}^{+} \mathrm{Cpe}^{+/+}$ males $(n=5), \mathrm{Tg}^{-}$Cpe fat/fat males $(n=6)$, proSAAS $\mathrm{Tg}^{+} \mathrm{Cpe}^{\text {fat } / \mathrm{fat}}$ males $(n=9), \mathrm{Tg}^{-} \mathrm{Cpe}^{+/+}$females $(n=4)$, proSAAS Tg $\mathrm{Cpe}^{+/+}$ females $(n=4), \mathrm{Tg}^{-}$Cpe fat/fat females $(n=9)$, and proSAAS $\mathrm{Tg}^{+}$ Cpe fat/fat females $(n=8)$.

same time point, but this also was not statistically significant. Because the RIA for insulin detects human proinsulin and the processing intermediates, and therefore presumably also detects mouse proinsulin and intermediates, we also examined the pancreas of the various lines of mice using a mouse monoclonal antibody specific for proinsulin (Orci et al. 1985). The islets in $\mathrm{Tg}^{-} \mathrm{Cpe}^{+/+}$ mice showed only weak and scattered ir-proinsulin (Fig. 7A). ProSAAS $\mathrm{Tg}^{+} \mathrm{Cpe} e^{+/+}$mice showed stronger staining

Table 1 Analysis of serum levels of various substances in $\mathrm{Tg}^{+}$and $\mathrm{Tg}^{-}$male Cpe ${ }^{+/+}$and $\mathrm{Cpe}$ fat/fat mice.

Results are means \pm S.E.M.

\begin{tabular}{|c|c|c|c|c|}
\hline & \multicolumn{2}{|l|}{$C p \mathrm{e}^{+/+}$mice } & \multicolumn{2}{|c|}{$C p \mathrm{e}^{\text {fat/fat }}$ mice } \\
\hline & $\mathrm{Tg}^{-}(n=3)$ & $\operatorname{Tg}^{+}(n=4)$ & $\mathrm{Tg}^{-}(n=3)$ & $\operatorname{Tg}^{+}(n=4)$ \\
\hline \multicolumn{5}{|l|}{ Compound } \\
\hline Glucose (fed) (mg/dl) & $218 \pm 17$ & $204 \pm 8$ & $479 \pm 160$ & $1060 \pm 84^{*}$ \\
\hline Cholesterol (mg/dl) & $97 \pm 3$ & $89 \pm 6$ & $105 \pm 9$ & $180 \pm 22^{*}$ \\
\hline BUN/creatine & $123 \pm 20$ & $230 \pm 10^{*}$ & $143 \pm 30$ & $117 \pm 47$ \\
\hline Albumin (g/dl) & $3 \cdot 1 \pm 0 \cdot 1$ & $3 \cdot 0 \pm 0 \cdot 1$ & $3 \cdot 1 \pm 0 \cdot 2$ & $3 \cdot 4 \pm 0 \cdot 2$ \\
\hline Total protein (g/dl) & $5 \cdot 2 \pm 0 \cdot 1$ & $5 \cdot 1 \pm 0 \cdot 1$ & $5 \cdot 1 \pm 0 \cdot 4$ & $5 \cdot 9 \pm 0 \cdot 2$ \\
\hline$P(\mathrm{mg} / \mathrm{dl})$ & $11 \cdot 4 \pm 0 \cdot 7$ & $9 \cdot 8 \pm 0 \cdot 3$ & $11 \cdot 9 \pm 1 \cdot 7$ & $11 \cdot 8 \pm 0 \cdot 8$ \\
\hline $\mathrm{Na}(\mathrm{meq} / \mathrm{l})$ & $152 \pm 2$ & $157 \pm 1$ & $157 \pm 2$ & $151 \pm 2$ \\
\hline $\mathrm{K}(\mathrm{meq} / \mathrm{l})$ & $10 \cdot 9 \pm 0 \cdot 3$ & $9 \cdot 2 \pm 0 \cdot 4$ & $11 \cdot 1 \pm 1 \cdot 6$ & $9 \cdot 5 \pm 0 \cdot 5$ \\
\hline $\mathrm{Ca}(\mathrm{mg} / \mathrm{dl})$ & $6 \cdot 4 \pm 1 \cdot 3$ & $8 \cdot 5 \pm 0 \cdot 7$ & $8 \cdot 5 \pm 0 \cdot 2$ & $9 \cdot 8 \pm 0 \cdot 7$ \\
\hline $\mathrm{Cl}(\mathrm{meq} / \mathrm{l})$ & $107 \pm 4$ & $113 \pm 1$ & $105 \pm 4$ & $104 \pm 2$ \\
\hline Mg (meq/l) & $1 \cdot 9 \pm 0 \cdot 1$ & $1 \cdot 7 \pm 0 \cdot 1$ & $2 \cdot 0 \pm 0 \cdot 1$ & $2 \cdot 1 \pm 0 \cdot 1$ \\
\hline
\end{tabular}

${ }^{*} P<0.05$ vs $\mathrm{Tg}^{-}$. 
Table 2 Fasting serum insulin levels $(\mathrm{ng} / \mathrm{ml})$ in proSAAS $\mathrm{Tg}^{+}$ $\mathrm{Cpe}^{+/+}$and $\mathrm{Tg}^{-} \mathrm{Cpe}^{+/+}$mice. Results are means \pm S.E.M.
Insulin at 2-3.5 months

Gender

(n)

Insulin at

4.5-6 months

(n)

\section{Genotype}

$\mathrm{Tg}^{+}$

$\mathrm{Tg}^{-}$

$\mathrm{Tg}^{+}$

$\mathrm{Tg}^{-}$
$1 \cdot 1 \pm 0 \cdot 3(14)$

$3 \cdot 8 \pm 2 \cdot 1(7)$

$4 \cdot 2 \pm 1 \cdot 3(15$

$3 \cdot 4 \pm 1 \cdot 3(5)$

Female
Female
Male
Male

for proinsulin (Fig. 7B), consistent with a decrease in the processing of proinsulin into insulin due to inhibition of PC1 by the elevated proSAAS expression in these mice. CPE-deficient Cpe fat fat mice showed strong staining for proinsulin (Fig. 7C,D), consistent with a previous report that these mice do not efficiently process proinsulin into insulin (Naggert et al. 1995). Because of the high level of proinsulin in the Cpe fat fat mice, it was not possible to detect a difference between the proSAAS $\mathrm{Tg}^{+}$and $\mathrm{Tg}^{-}$ Cpe fat/fat mice. In addition to proinsulin, we also examined the distribution of insulin in the four lines. All four groups of animals showed comparable staining for insulin (data not shown), consistent with the RIA data (although the antiserum used for immunohistochemistry also cross reacts with proinsulin).

To accurately compare peptide levels in proSAAS $\mathrm{Tg}^{+}$ and $\mathrm{Tg}^{-}$mice, we used a novel method that we recently developed to examine relative neuropeptide levels in Cpe fat fat mice (Che \& Fricker 2002). This method uses differential isotopic labeling and mass spectrometry to quantitatively compare levels in two different samples.
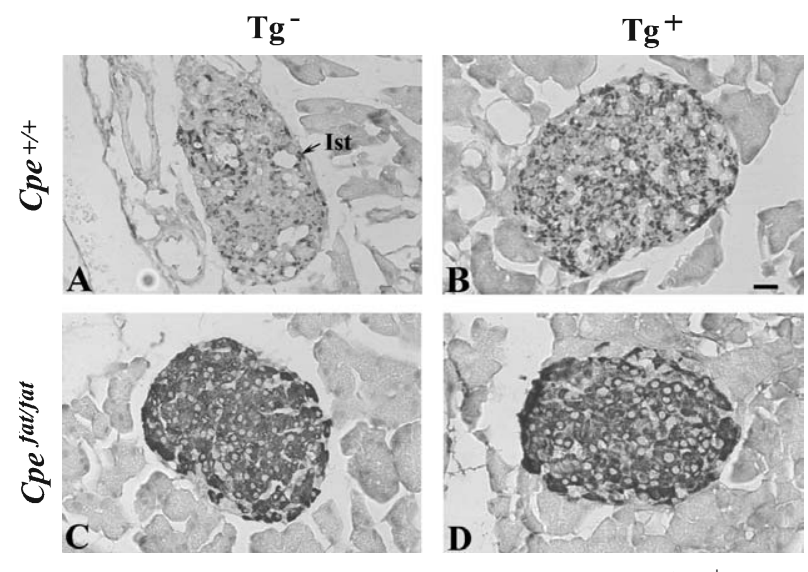

Figure 7 Proinsulin immunoreactivity in the pancreas of $\mathrm{Tg}^{+}$and $\mathrm{Tg}^{-}$mice. (A) $\mathrm{Tg}^{-} \mathrm{Cpe}^{+/+}$female, 22 weeks. The arrow indicates the Islets of Langerhan's (Ist). (B) proSAAS Tg ${ }^{+} \mathrm{Cpe}^{+/+}$female, 22 weeks; (C) $\mathrm{Tg}^{-}$Cpe fat/fat female, 18 weeks; (D) proSAAS Tg ${ }^{+}$ Cpe fat/fat female, 14 weeks. The bar (panel B) represents $100 \mu \mathrm{m}$. The experiment was replicated twice with additional animals and similar results were obtained.
Altogether, eight pools of pituitary glands were compared for $\mathrm{Cpe}^{+/+}$mice and four pools of pituitary glands were compared for Cpe fat fat mice; each pool consisted of one $\mathrm{Tg}^{+}$mouse pituitary and one $\mathrm{Tg}^{-}$mouse pituitary (pooled after labeling with either light or heavy acetic anhydride). For the $\mathrm{Cpe}^{+/+}$mice, nine distinct peptides were observed that were quantifiable (i.e. the heavy and light peaks were sufficiently separated to permit measurement of peak intensity), ranging in mass from $739 \cdot 35$ to $2772.56 \mathrm{Da}$ (Table 3). Five of these peptides correspond to the mature forms of peptides previously identified in $C p e^{\text {fat fat }}$ mice pituitaries and which were sequenced using tandem mass spectrometry (Che et al. 2001). Of the four additional 'unknowns,' one of these corresponds to the theoretical mass of mouse gamma-melanocyte stimulating hormone (gamma-MSH; 1337.75 Da observed, 1337.63 Da theoretical), but since it was not sequenced by tandem mass spectrometry, it is listed as 'unknown'. Interestingly, none of the nine observed peptides is decreased in the $\mathrm{Tg}^{+} \mathrm{Cpe}^{+/+}$mice, relative to the $\mathrm{Tg}^{-}$ $\mathrm{Cpe}^{+/+}$mice (Table 3). Instead, the peptide levels are either unchanged (vasopressin and three of the unknowns) or significantly elevated (the four pro-opiomelanocortinderived peptides and the $1337 \cdot 75 \mathrm{Da}$ unknown peptide, which may represent the gamma-MSH fragment of proopiomelanocortin). This result implies that the level of proSAAS expression in the pituitary of $\mathrm{Cpe}^{+/+}$does not inhibit PC1 activity, and that the proSAAS transgene stimulated the expression of pro-opiomelanocortinderived peptides. In contrast to the results in $\mathrm{Cpe}^{+/+}$mice, when expressed in CPE-deficient Cpe fat fat mice the transgene significantly decreased the levels of vasopressin, J-peptide, corticotropin-like intermediate lobe peptide, and the $2772.56 \mathrm{Da}$ unknown peptide (Table 3). Only one peptide (alpha-MSH) is not significantly reduced in the $\mathrm{Tg}^{+} C p e^{\text {fat fat }}$ mice, relative to the $\mathrm{Tg}^{-} C p e^{\text {fat fat }}$ mice; the other peptides found in $\mathrm{Cpe}^{+/+}$mice are not detected in the Cpe fat fat mice, which are known to have lower levels of fully processed peptides relative to the $\mathrm{Cpe}^{+/+}$mice (Naggert et al. 1995, Fricker et al. 1996, Rovere et al. 1996, Cain et al. 1997, Udupi et al. 1997, Che et al. 2001). The transgene-induced decrease in pituitary peptide levels in Cpe fat fat mice is consistent with the inhibition of PC1 in the proSAAS-expressing mice.

The levels and forms of PC1 in brain of the various mice were examined by Western blotting with a C-terminally directed antiserum. As previously reported (Berman et al. 2001), the $68 \mathrm{kDa}$ form of PC1 is the predominant form in $\mathrm{Tg}^{-} \mathrm{Cpe}^{+/+}$and $\mathrm{Tg}^{-} \mathrm{Cpe}^{\text {fat } /+}$ mice (Fig. 8). In $\mathrm{Tg}^{-}$ Cpe fat fat mice, there is less of the $68 \mathrm{kDa}$ form and more of the $84 \mathrm{kDa}$ form, in addition to a larger form (Fig. 8). This larger form is only detected in the Cpe fat/fat mouse extract, and may correspond to an intermediate proPC1 form with unprocessed N-linked glycosylation. The relative level of the various forms of PC1 is not influenced by the presence or absence of the proSAAS transgene 
Table 3 Relative levels of various pituitary peptides in proSAAS $\mathrm{Tg}^{+}$mice, compared with age- and sex-matched $\mathrm{Tg}^{-}$mice

\begin{tabular}{|c|c|c|c|c|}
\hline & \multirow[b]{2}{*}{ Observed mass (Da) } & \multirow[b]{2}{*}{ Theoretical mass (Da) } & \multicolumn{2}{|c|}{ Relative ratio $\left(\mathrm{Tg}^{+} / \mathrm{Tg}^{-}\right) \pm$standard error (} \\
\hline & & & $\mathrm{Cpe}^{+/+}$mice & $\mathrm{Cpe}^{\text {fat } / \text { fat }}$ mice \\
\hline \multicolumn{5}{|l|}{ Peptide } \\
\hline Vasopressin & $1083 \cdot 55(\mathrm{~m})$ & $1083 \cdot 46(\mathrm{~m})$ & $0.96 \pm 0.06(8)$ & $0.49 \pm 0.08(4)^{\star *}$ \\
\hline alpha-MSH & $1663 \cdot 71(\mathrm{~m})$ & $1663 \cdot 80(\mathrm{~m})$ & $1.71 \pm 0.22(8)^{* *}$ & $0 \cdot 90 \pm 0 \cdot 11$ \\
\hline J-peptide & $1939.92(\mathrm{~m})$ & $1939 \cdot 86(\mathrm{~m})$ & $1 \cdot 30 \pm 0 \cdot 18(8)$ & $0 \cdot 47 \pm 0 \cdot 10(3)^{* *}$ \\
\hline$\gamma \mathrm{LPH}$ frag. ${ }^{(1)}$ & $1983.93(\mathrm{~m})$ & $1983.97(\mathrm{~m})$ & $1.73 \pm 0.27(3)^{* *}$ & \\
\hline CLIP & 2506.95 (a) & $2506 \cdot 80$ (a) & $1.62 \pm 0.28(7)^{*}$ & $0 \cdot 66 \pm 0 \cdot 10(4)^{* *}$ \\
\hline Unknown & $739 \cdot 35(\mathrm{~m})$ & & $0 \cdot 85 \pm 0 \cdot 20$ & \\
\hline Unknown ${ }^{(2)}$ & $1337 \cdot 75(\mathrm{~m})$ & & $1.96 \pm 0.28(8)^{* *}$ & \\
\hline Unknown & $1975 \cdot 00(\mathrm{~m})$ & & $0.99 \pm 0.25$ & \\
\hline Unknown & $2772 \cdot 56(\mathrm{a})$ & & $1 \cdot 04 \pm 0 \cdot 05(6)$ & $0.45 \pm 0.05(2)^{* *}$ \\
\hline
\end{tabular}

Observed and theoretical masses are either monoisotopic $(\mathrm{m})$ or average (a), as determined from analysis of the spectra.

${ }^{(1)} \gamma \mathrm{LPH}$ frag., gamma lipotrophic hormone fragment=GPYRVEHFRWSNPPKD; ${ }^{(2)}$ possible gamma-MSH related pro-opiomelanocortin peptide KYVMGHFRWD (1337.63 m).

${ }^{*} P<0 \cdot 05 ;{ }^{* *} P<0 \cdot 01$ compared with standard peptides tested at equimolar amounts (e.g. a ratio of $1 \cdot 0$ ).

(compare lanes 1 and 2 or lanes 3 and 4, Fig. 8). Thus, the effect of the proSAAS transgene on the apparent PC1 activity is not due to alterations in the levels or forms of PC1 protein.

\section{Discussion}

Although proSAAS-derived peptides were initially discovered in Cpe fat fat mice which show adolescent-onset obesity, it was not clear whether these peptides contributed to the obesity phenotype. A large number of known peptides were also identified using the same technique that was used to discover the proSAAS-derived peptides (Fricker et al. 2000, Che et al. 2001), and many of these other peptides are not thought to be involved in body weight regulation. Based on the previous finding that proSAAS and some proSAAS-derived peptides potently inhibit PC1, it was predicted that proSAAS transgenic mice would resemble mice with a disruption in the PC1 gene (PC1 knock-out (KO) mice). However, the phenotype of PC1 KO mice is much different from that observed for the proSAAS transgenic mice. The PC1 KO mice are much smaller than wild-type mice, presumably due to a deficiency in growth hormone-releasing hormone production (Zhu et al. 2002a). A human mutation of PC1 has been reported to have the opposite phenotype extreme, early-onset obesity (Jackson et al. 1997). This also differs from the moderate adolescence-onset obesity observed in the proSAAS $\mathrm{Tg}^{+}$mice. Taken together with our finding that proSAAS $\mathrm{Tg}^{+} \mathrm{Cpe}+{ }^{+/+}$mice are not defective in their processing of pituitary peptides, it suggests that the level of proSAAS expression in the transgenic mice is not sufficient to substantially impair PC1 activity in the pituitary. Thus, the moderate obesity observed in these mice is likely due to another action of
proSAAS and/or the proSAAS-derived peptides, possibly as neuropeptides. In addition to the evidence cited above, it is unlikely that the proSAAS transgene-mediated increase in body weight observed in the $\mathrm{Cpe}^{+/+}$mice is due to inhibition of PC1 because this phenotype is not more pronounced in the $\mathrm{Tg}^{+} \mathrm{Cp} e^{\text {fat fat }}$ mice, which clearly have a greater impairment of PC1 activity than the $\mathrm{Tg}^{+}$ $\mathrm{Cpe}^{+/+}$mice.
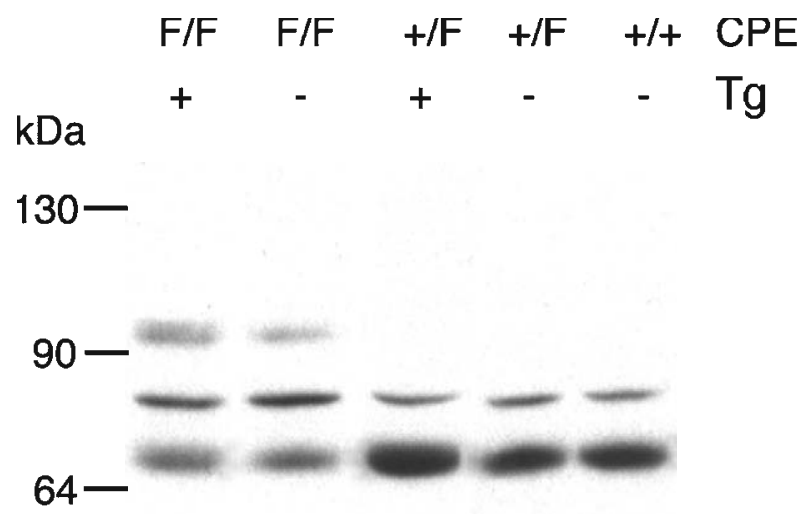

53

Figure 8 Western blot analysis of PC1 in proSAAS $\mathrm{Tg}^{+}$and $\mathrm{Tg}^{-}$ mice. Brain extracts were fractionated on a denaturing $8 \%$ polyacrylamide gel, transferred to nitrocellulose, and probed with an antiserum raised against the $\mathrm{N}$-terminal region of $\mathrm{PC} 1$. The genotype is shown at the top of the figure. The positions and masses (in $\mathrm{kDa}$ ) of the prestained protein standards are indicated. The experiment was replicated twice with additional animals and similar results were obtained. 
ProSAAS mRNA and proSAAS-derived peptides are present at relatively high levels in the hypothalamus, and in particular in nuclei implicated in body weight regulation (Fricker et al. 2000, Feng et al. 2001). A large number of other peptides have been implicated in the regulation of body weight, including neuropeptide Y, galanin, melanocyte-stimulating hormone, melanin-concentrating hormone, cocaine- and amphetamine-regulated transcript, agouti-related peptide, corticotropin-releasing hormone, glucagon-like peptide-1, urocortin, leptin, ghrelin, and several others $(\mathrm{Qu}$ et al. 1996, Spina et al. 1996, Turton et al. 1996, Mizuno et al. 1999, Altman 2002, Schwartz \& Morton 2002, Torri et al. 2002, Wilding 2002). Some of these were first identified as candidates for body weight regulation from studies involving transgenic or knock-out mice. In contrast, other peptides that cause substantial changes in body weight when administered to mice or rats fail to alter body weight when the gene is disrupted (Erickson et al. 1996). Thus, the regulation of body weight is a very complex system that shows plasticity, an inherent problem in studies using transgenic and/or knock-out mice. In addition to the various peptides, other gene products have been implicated in body weight regulation from studies involving transgenic mice, knock-out mice, or mice with naturally-occurring mutations; examples include various receptors (Chen et al. 1996, Huszar et al. 1997, Chen et al. 2000, Marsh et al. 2002), secreted proteins (Hahm et al. 1999, Collier et al. 2000), and enzymes (Naggert et al. 1995, Masuzaki et al. 2001).

The increase in pro-opiomelanocortin-derived peptides in the proSAAS- $\mathrm{Tg}^{+} \mathrm{Cpe}^{+/+}$mice is clearly not the result of inhibition of PC1 activity; these peptides are terminal processing products and not just intermediates in the processing pathway. Also, because the levels of vasopressin and three of the unidentified peptides were not substantially affected by the expression of the proSAAS transgene, it is unlikely that there was significant inhibition of PC1 in the $\mathrm{Cpe}^{+/+}$mice pituitary. Instead, it is possible that pro-opiomelanocortin gene expression was induced, either directly as a result of the elevated levels of proSAASderived peptides, or indirectly due to a consequence of the proSAAS expression. Further studies are needed to investigate whether pro-opiomelanocortin mRNA is directly elevated by proSAAS expression, and to determine the mechanism of the apparent increase in proopiomelanocortin-derived peptides in proSAAS transgenic animals. Interestingly, pro-opiomelanocortin mRNA levels are substantially elevated in mice with a disruption in the PC1 gene (Zhu et al. 2002a,b).

The decrease in vasopressin levels in the proSAAS- $\mathrm{Tg}^{+}$ Cpe fat fat mice, relative to $\mathrm{Tg}^{-}$Cpe fat/fat mice, is consistent with a role for PC1 in the processing of provasopressin. PC1 has been co-localized with provasopressin in the hypothalamic nuclei that project to the posterior pituitary (Dong et al. 1997). In addition, PC2 and other related PCs are expressed in the provasopressin-containing nuclei (Dong et al. 1997), suggesting that multiple enzymes contribute towards the processing of this precursor. Similarly, pro-opiomelanocortin-expressing cells in the intermediate lobe of the pituitary also express both PC1 and PC2, and both enzymes are thought to be involved in pro-opiomelanocortin processing. Because proSAAS and the PEN-containing processing intermediates (Fig. 1) are relatively selective as inhibitors of PC1 (Qian et al. 2000, Basak et al. 2001), the overexpression of proSAAS in the Cpe $e^{\text {fat fat }}$ mice would presumably only reduce PC1 activity. If this is correct, then PC1 contributes to at least $50 \%$ of the processing of provasopressin into vasopressin and pro-opiomelanocortin into J-peptide, based on the decrease of these peptides in proSAAS $\mathrm{Tg}^{+}$mice relative to $\mathrm{Tg}^{-}$Cpe fat fat mice.

The three founder mice showed a strong correlation between the level of proSAAS expression in the brain and the degree of obesity, with the highest expresser approximately $70 \mathrm{~g}$ at 45 weeks of age. Unfortunately, this mouse was not fertile. Although the fertile male that expressed moderately elevated levels of proSAAS mRNA (mouse 32) was only 5-10 g overweight, the expression levels of the proSAAS-derived peptides in mice derived from this founder were only 60-90\% above the $\mathrm{Tg}^{-}$littermates, suggesting that a reasonably small increase in these peptides has a significant effect on body weight. In addition to the correlation between proSAAS expression and obesity in the three founder mice noted above, line 32 itself served as its own control; during the backcrossing of the proSAAS transgene into the BKS background, some of the $\mathrm{Tg}^{+}$ offspring failed to express the proSAAS-derived peptides and these mice were no longer overweight relative to $\mathrm{Tg}^{-}$littermates (data not shown). In addition, when crossed into the Cpe fat fat mice, the $\mathrm{Tg}^{+}$mice that no longer expressed the proSAAS-derived peptides survived through 35 weeks (data not shown). Thus, even though the proSAAS transgene was still present in the genome, and any interrupted gene would still be inactivated, the mice that lost the expression of the proSAAS protein also lost the increased body weight phenotype (in the Cpe $e^{+/+}$ mice) and the adolescent-onset mortality (in the Cpe fat fat mice). Taken together, these results support the hypothesis that proSAAS and/or proSAAS-derived peptides function in the regulation of body weight, either as inhibitors of PC1 activity or directly as neuropeptides.

\section{Acknowledgements}

Microscopy was performed in the Analytical Imaging Facility of Albert Einstein College of Medicine. Glucose measurements were performed in the laboratory of Dr Luciano Rossetti, Department of Medicine, Albert Einstein College of Medicine. Special thanks to Drs James Douglass, Ed Leiter, and Luciano Rossetti for helpful 
discussions, Reeta Biswas for technical assistance with the mice, and Steven Tresker for assistance with the quantitation of the mass spectrometry data. The antibody to proinsulin was generously provided by Dr Ole D Madsen, Director of Research, Hagedorn Research Institute, Niels Steensensvej 6, DK-2820 Gentofte, Denmark.

\section{Funding}

This work was primarily supported by National Institutes of Health grant DA-04494 (to L D F). Radioimmunoassay and Western blot analyses were supported by grant NS26880 (to L A D). Mass spectrometry was performed in the Laboratory for Macromolecular Analysis of the Albert Einstein College of Medicine, which is supported in part by the Cancer Center Grant CA13330 and by the Diabetes Research Training Center Grant DK20541.

\section{References}

Altman J 2002 Weight in the balance. Neuroendocrinology 76 131-136.

Basak A, Koch P, Dupelle M, Fricker LD, Devi LA, Chretien M \& Seidah NG 2001 Inhibitory specificity and potency of proSAASderived peptides toward proprotein convertase 1. Journal of Biological Chemistry 276 32720-32728.

Berman Y, Mzhavia N, Polonskaia A \& Devi LA 2001 Impaired prohormone convertases in Cpe $e^{\text {fat }} / \mathrm{Cpe}^{\text {fat }}$ mice. Journal of Biological Chemistry 276 1466-1473.

Cain BM, Wang W \& Beinfeld MC 1997 Cholecystokinin (CCK) levels are greatly reduced in the brains but not the duodenums of $C p e^{\text {fat }} / C p e^{\text {fat }}$ mice: a regional difference in the involvement of carboxypeptidase E (Cpe) in pro-CCK processing. Endocrinology 138 4034-4037.

Cameron A, Fortenberry Y \& Lindberg I 2000 The SAAS granin exhibits structural and functional homology to 7B2 and contains a highly potent hexapeptide inhibitor of PC1. FEBS Letters $\mathbf{4 7 3}$ 135-138.

Che F-Y \& Fricker LD 2002 Quantitation of neuropeptides in $C p e^{f a t} / C p e^{\text {fat }}$ mice using differential isotopic tags and mass spectrometry. Annals of Chemistry 74 3190-3198.

Che F-Y, Yan L, Li H, Mzhavia N, Devi L \& Fricker LD 2001 Identification of novel peptides from brain and pituitary of Cpe fat $_{\text {Cpe }}^{\text {fat }}$ mice. PNAS 98 9971-9976.

Chen AS, Marsh DJ, Trumbauer ME, Frazier EG, Guan XM, Yu H, Rosenblum CI, Vongs A, Feng Y, Cao L, Metzger JM, Strack AM, Camacho RE, Mellin TN, Nunes CN, Min W, Fisher J, Gopal-Truter S, MacIntyre DE, Chen HY \& Van der Ploeg LH 2000 Inactivation of the mouse melanocortin-3 receptor results in increased fat mass and reduced lean body mass. Nature Genetics 26 97-102.

Chen H, Charlat O, Tartaglia LA, Woolf EA, Weng X, Ellis SJ, Lakey ND, Culpepper J, Moore KJ, Breitbart RE, Duyk GM, Tepper RI \& Morgenstern JP 1996 Evidence that the diabetes gene encodes the leptin receptor: identification of a mutation in the leptin receptor gene in $\mathrm{db} / \mathrm{db}$ mice. Cell 84 491-495.

Collier GR, McMillan JS, Windmill K, Walder K, Tenne-Brown J, De Silva A, Trevaskis J, Jones S, Morton GJ, Lee S, Augert G, Civitarese A \& Zimmet PZ 2000 Beacon: a novel gene involved in the regulation of energy balance. Diabetes 49 1766-1771.

Davidsson P, Sjogren M, Andreasen N, Lindbjer M, Nilsson CL, Westman-Brinkmalm A \& Blennow K 2002 Studies of the pathophysiological mechanisms in frontotemporal dementia by proteome analysis of CSF proteins. Brain Research Molecular Brain Research 109 128-133.

Dong W, Seidel B, Marcinkiewicz M, Chretien M, Seidah NG \& Day R 1997 Cellular localization of the prohormone convertases in the hypothalamic paraventricular and supraoptic nuclei: selective regulation of $\mathrm{PC} 1$ in corticotrophin-releasing hormone parvocellular neurons mediated by glucocorticoids. Journal of Neuroscience $\mathbf{1 7}$ $563-575$.

Erickson JC, Hollopeter G \& Palmiter RD 1996 Attenuation of the obesity syndrome of ob/ob mice by the loss of neuropeptide Y. Science 274 1704-1707.

Feistner GJ, Hojrup P, Evans CJ, Barofsky DF, Faull KF \& Roepstorff P 1989 Mass spectrometric charting of bovine posterior/ intermediate pituitary peptides. PNAS 86 6013-6017.

Feng Y, Reznik SE \& Fricker LD 2001 Distribution of proSAAS-derived peptides in rat neuroendocrine tissues. Neuroscience 105 469-478.

Fricker LD 1998a Carboxypeptidase E/H. In Handbook of Proteolytic Enzymes, pp 1341-1344. Eds AJ Barrett, ND Rawlings \& JF Woessner. San Diego: Academic Press.

Fricker LD 1998b Metallocarboxypeptidase D. In Handbook of Proteolytic Enzymes, pp 1349-1351. Eds AJ Barrett, ND Rawlings \& JF Woessner. San Diego: Academic Press.

Fricker LD 2002 Carboxypeptidases E and D. In The Enzymes, Volume 23: Co- and Posttranslational Proteolysis of Proteins, edn 3, pp 421-452. Eds RE Dalbey \& DS Sigman. San Diego: Academic Press.

Fricker LD, Berman YL, Leiter EH \& Devi LA 1996 Carboxypeptidase $\mathrm{E}$ activity is deficient in mice with the fat mutation: effect on peptide processing. Journal of Biological Chemistry 271 30619-30624.

Fricker LD, McKinzie AA, Sun J, Curran E, Qian Y, Yan L, Patterson SD, Courchesne PL, Richards B, Levin N, Mzhavia N, Devi LA \& Douglass J 2000 Identification and characterization of proSAAS, a granin-like neuroendocrine peptide precursor that inhibits prohormone processing. Journal of Neuroscience 20 639-648.

Graham M, Shutter JR, Sarmiento U, Sarosi I \& Stark KL 1997 Overexpression of Agrt leads to obesity in transgenic mice. Nature Genetics 17 273-274.

Hahm S, Mizuno TM, Wu TJ, Wisor JP, Priest CA, Kozak CA, Boozer CN, Peng B, McEvoy RC, Good P, Kelley KA, Takahashi JS, Pintar JE, Roberts JL, Mobbs CV \& Salton SRJ 1999 Targeted deletion of the Vgf gene indicates that the encoded secretory peptide precursor plays a novel role in the regulation of energy balance. Neuron 23 537-548.

Huszar D, Lynch CA, Fairchild-Huntress V, Dunmore JH, Fang Q, Berkemeier LR, Gu W, Kesterson RA, Boston BA, Cone RD, Smith FJ, Campfield LA, Burn P \& Lee F 1997 Targeted disruption of the melanocortin-4 receptor results in obesity in mice. Cell 88 131-141.

Jackson RS, Creemers JWM, Ohagi S, Raffin-Sanson M, Sanders L, Montague CT, Hutton JC \& O'Rahilly S 1997 Obesity and impaired prohormone processing associated with mutations in the human prohormone convertase 1 gene. Nature Genetics 16 303-306.

Jimenez CR, Li KW, Dreisewerd K, Mansvelder HD, Brussaard AB, Reinhold BB, Van der Schors RC, Karas M, Hillenkamp F, Burbach JPH, Costello CE \& Geraerts WPM 1997 Pattern changes of pituitary peptides in rat after salt-loading as detected by means of direct, semiquantitative mass spectrometric profiling. PNAS 94 9481-9486.

Leiter EH, Kintner J, Flurkey K, Beamer WG \& Naggert JK 1999 Physiologic and endocrinologic characterization of male sex-biased diabetes in C57 BLKS/J mice congenic for the fat mutation at the carboxypeptidase E locus. Endocrine 10 57-66. 
Marcinkiewicz M, Benjannet S, Seidah NG, Cantin M \& Chretien M 1987 The pituitary polypeptide '7B2' is associated with LH/FSH and TSH cells and is localized within secretory vesicles. Cell Tissue Research 250 205-214.

Marsh DJ, Weingarth DT, Novi DE, Chen HY, Trumbauer ME, Chen AS, Guan XM, Jiang MM, Feng Y, Camacho RE, Shen Z, Frazier EG, Yu H, Metzger JM, Kuca SJ, Shearman LP, Gopal-Truter S, MacNeil DJ, Strack AM, MacIntyre DE, Van der Ploeg LH \& Qian S 2002 Melanin-concentrating hormone 1 receptor-deficient mice are lean, hyperactive, and hyperphagic and have altered metabolism. PNAS 99 3240-3245.

Martens GJ, Braks JA, Eib DW, Zhou Y \& Lindberg I 1994 The neuroendocrine polypeptide $7 \mathrm{~B} 2$ is an endogenous inhibitor of prohormone convertase PC2. PNAS 91 5784-5787.

Masuzaki H, Paterson J, Shinyama H, Morton NM, Mullins JJ, Seckl JR \& Flier JS 2001 A transgenic model of visceral obesity and the metabolic syndrome. Science 294 2166-2170.

Mizuno TM, Makimura H, Silverstein J, Roberts JL, Lopingco T \& Mobbs CV 1999 Fasting regulates hypothalamic neuropeptide Y, agouti-related peptide, and pro-opiomelanocortin in diabetic mice independent of changes in leptin or insulin. Endocrinology 140 4551-4557.

Mzhavia N, Berman Y, Che F, Fricker LD \& Devi LA 2001 ProSAAS processing in mouse brain and pituitary. Journal of Biological Chemistry 276 6207-6213.

Mzhavia N, Qian Y, Feng Y, Che F, Devi LA \& Fricker LD 2002 Processing of proSAAS in neuroendocrine cell lines. Biochemistry Journal 361 67-76.

Naggert JK, Fricker LD, Varlamov O, Nishina PM, Rouille Y, Steiner DF, Carroll RJ, Paigen BJ \& Leiter EH 1995 Hyperproinsulinemia in obese fat/fat mice associated with a point mutation in the carboxypeptidase $\mathrm{E}$ gene and reduced carboxypeptidase E activity in the pancreatic islets. Nature Genetics $10135-142$

Orci L, Ravazzola M, Amherdt M, Madsen O, Vassalli JD \& Perrelet A 1985 Direct identification of prohormone conversion site in insulin-secreting cells. Cell 42 671-681.

Qian Y, Devi LA, Mzhavia N, Munzer S, Seidah NG \& Fricker LD 2000 The C-terminal region of proSAAS is a potent inhibitor of prohormone convertase 1. Journal of Biological Chemistry 275 23596-23601.

Qu D, Ludwig DS, Gammeltoft S, Piper M, Pelleymounter MA, Cullen MJ, Mathes WF, Przypek J, Kanarek R \& Maratos-Flier E 1996 A role for melanin-concentrating hormone in the central regulation of feeding behaviour. Nature 380 243-247.

Rovere C, Viale A, Nahon J \& Kitabgi P 1996 Impaired processing of brain proneurotensin and promelanin-concentrating hormone in obese fat/fat mice. Endocrinology 137 2954-2958.

Schwartz MW \& Morton GJ 2002 Obesity: keeping hunger at bay. Nature 418 595-597.
Seidah NG \& Chretien M 1998a Prohormone convertase 2. In Handbook of Proteolytic Enzymes, pp 345-357. Eds AJ Barrett, ND Rawlings \& JF Woessner. San Diego: Academic Press.

Seidah NG \& Chretien M 1998b Proprotein convertase I. In Handbook of Proteolytic Enzymes, pp 349-353. Eds AJ Barrett, ND Rawlings \& JF Woessner. San Diego: Academic Press.

Spina M, Merlo-Pich E, Chan RK, Basso AM, Rivier J, Vale W \& Koob GF 1996 Appetite-suppressing effects of urocortin, a CRF-related neuropeptide. Science 273 1561-1564.

Torri C, Pedrazzi P, Leo G, Muller EE, Cocchi D, Agnati LF \& Zoli M 2002 Diet-induced changes in hypothalamic pro-opiomelanocortin mRNA in the rat hypothalamus. Peptides $\mathbf{2 3}$ $1063-1068$.

Turton MD, O'Shea D, Gunn I, Beak SA, Edwards CMB, Meeran K, Choi SJ, Taylor GM, Heath MM, Lambert PD, Wilding JPH, Smith DM, Ghatei MA, Herbert J \& Bloom SR 1996 A role for glucagon-like peptide-1 in the central regulation of feeding. Nature 379 69-74.

Udupi V, Gomez P, Song L, Varlamov O, Reed JT, Leiter EH, Fricker LD \& Greeley GHJ 1997 Effect of carboxypeptidase E deficiency on progastrin processing and gastrin mRNA expression in mice with the fat mutation. Endocrinology 138 1959-1963.

Vindrola O \& Lindberg I 1992 Biosynthesis of the prohormone convertase mPC1 in AtT-20 cells. Molecular Endocrinology 6 1088-1094.

Wilding JP 2002 Neuropeptides and appetite control. Diabetes Medecine 19 619-627.

Young E, Bronstein D \& Akil H 1993 Pro-opiomelanocortin biosynthesis, processing and secretion: functional implications. In Opioids I, edn 1, pp 393-421. Eds A Herz, H Akil \& EJ Simon. Berlin: Springer-Verlag.

Zhou A, Webb G, Zhu X \& Steiner DF 1999 Proteolytic processing in the secretory pathway. Journal of Biological Chemistry $\mathbf{2 7 4}$ 20745-20748.

Zhu X, Orci L, Carroll R, Norrbom C, Ravazzola M \& Steiner DF $2002 a$ Severe block in processing of proinsulin to insulin accompanied by elevation of des-64,65 proinsulin intermediates in islets of mice lacking prohormone convertase 1/3. PNAS 99 10299-10304.

Zhu X, Zhou A, Dey A, Norrbom C, Carroll R, Zhang C, Laurent V, Lindberg I, Ugleholdt R, Holst JJ \& Steiner DF $2002 b$ Disruption of PC1/3 expression in mice causes dwarfism and multiple neuroendocrine peptide processing defects. PNAS 99 10293-10298.

Received 20 November 2003

Accepted 11 December 2003

Made available online as an

Accepted Preprint 19 December 2003 